\title{
BELI ATAU TIDAK? PERAN ELECTRONIC WORD OF MOUTH (eWOM) DAN KEPRIBADIAN MEREK TERHADAP KEPUTUSAN PEMBELIAN PADA MEREK KOSMETIK LOKAL
}

\author{
Irfan Aulia Syaiful, Ade Pungki Royani \\ Fakultas Psikologi, Universitas Mercu Buana \\ Jalan Meruya Selatan No 1. Meruya Selatan, Kembangan, Jakarta Barat, Jakarta 11650 \\ E-mail: irfan.aulia@mercubuana.ac.id
}

\begin{abstract}
ABSTRAK
Penelitian yang membahas tentang kepribadian merek dan fenomena electronic word of mouth masih sangat menarik untuk ditelaah. Studi ini meneliti peran electronic word of mouth dan kepribadian merek terhadap keputusan pembelian khususnya dalam konteks pembelian produk kosmetik merek lokal. Partisipan dalam penelitian ini terdiri dari 439 perempuan berusia 20-34 tahun yang minimum telah membeli produk kosmetik merek lokal (Make Over) sebanyak satu kali. Untuk mengukur electronic word of mouth digunakan alat ukur electronic word of mouth scale, sementara kepribadian merek diukur dengan brand personality scale, dan keputusan pembelian diukur dengan alat ukur keputusan pembelian. Hasil penelitian menunjukkan variabel kepribadian merek dan electronic word of mouth baik berdiri sendiri ataupun secara bersama-sama mempunyai peran yang sangat kuat memprediksi keputusan pembelian pada merek kosmetik lokal. Hal ini menggambarkan pentingnya merek kosmetik lokal membangun kepribadian merek yang kuat dan menggunakan pesan viral dari mulut ke mulut pada media digital untuk mempengaruhi keputusan pembelian pada konsumennya.
\end{abstract}

Kata kunci: electronic word of mouth, kepribadian merek, keputusan pembelian, merek lokal

\section{BUY OR NOT? THE ROLE OF ELECTRONIC-WORD OF MOUTH (eWOM) AND BRAND PERSONALITY ON PURCHASE DECISIONS OF COSMETICS LOCAL BRAND}

\begin{abstract}
Research discussing the brand personality and phenomenon of electronic word of mouth is still very interesting to be studied. The study examines the role of electronic word of mouth and brand personality against purchasing decisions especially in the context of purchasing local brand cosmetic products. The participants in this study consisted of 439 women aged 20-34 years who have at least bought a brand cosmetic product from local cosmetic brand (Make Over) products once. Electronic word of mouth was measured with instrument electronic word of mouth scale, while brand personality was measured with brand personality scale, and purchase decision was measured with purchasing decision scale. The results showed the brand personality variables and the electronic word of mouth either stand alone or jointly have a very strong role in predicting purchasing decisions on local cosmetic brands. This illustrates the importance of local cosmetic brands building strong brand personalities and using viral messages from word of mouth in online media to influence purchasing decisions on consumers.
\end{abstract}

Keyword: brand personality, electronic word of mouth, purchase decisions, local brand

\section{PENDAHULUAN}

Berbicara masalah wanita, tentunya tidak lepas dari kata kecantikan, baik itu kecantikan dari dalam maupun dari luar diri wanita. Kecantikan diri, khususnya kecantikan pada fisik atau penampilan, sering dirasakan oleh kaum hawa untuk meningkatkan rasa percaya dirinya. Sama seperti pakaian, penggunaan produk kosmetik dapat meningkatkan penampilan seseorang dan digunakan untuk mengomunikasikan gaya atau preferensi estetika seseorang (Guthrie, Kim, \& Jung, 2008).

Berbagai cara dan usaha dilakukan oleh para wanita untuk dapat mempercantik penampilannya, 
salah satunya dengan penggunaan produk-produk kosmetik. Beragam macam dan jenis produk kosmetik telah hadir di pasaran. Tersedianya beragam pilihan ini pun memudahkan para wanita untuk memilih produk kosmetik yang memang sesuai dengan kebutuhannya.

Tabel 1. Perkembangan Pasar Industri Kosmetik di Indonesia, 2010-2015

\begin{tabular}{|c|c|c|}
\hline Tahun & $\begin{array}{c}\text { Market (Rp. } \\
\text { Milyar) }\end{array}$ & $\begin{array}{c}\text { Kenaikan } \\
(\%)\end{array}$ \\
\hline 2010 & 8,900 & - \\
\hline 2011 & 8,500 & $-4,49$ \\
\hline 2012 & 9,760 & 14,82 \\
\hline 2013 & 11,200 & 14,75 \\
\hline 2014 & 12,874 & 14,95 \\
\hline $2015 *)$ & 13,943 & 8,30 \\
\hline \multicolumn{2}{|c|}{ Kenaikan Rata-Rata (\%/tahun) } & 9,67 \\
\hline \multicolumn{3}{|c|}{$\begin{array}{l}\text { *) Angka Sementara } \\
\text { Sumber: Survey Bizteka-CCI (http://cci- } \\
\text { indonesia.com/) }\end{array}$} \\
\hline
\end{tabular}

Dari data Tabel 1 tersebut dapat disimpulkan bahwa pasar industri kosmetik di Indonesia pada tahun 2010 hingga 2015 mengalami kenaikan rata-rata per tahunnya sebesar $9,67 \%$.

Dengan terus berkembangnya industri kosmetik di Indonesia, tentu persaingan yang terjadi antarprodusen kosmetik juga meningkat. Tiap produsen tersebut berusaha menarik perhatian masyarakat untuk membeli produk kosmetik keluarannya. Hasil dari penelitian yang diselesaikan pada Mei 2017 tersebut menunjukkan bahwa 85\% produk perawatan kulit dan 53\% untuk kosmetik merek lokal masih mendominasi konsumen Indonesia (Prihatini, 2017).

Pada tahun 2019, data dari Kemenperin menunjukkan bahwa ekspor produk kosmetik lokal sudah berada di angka US \$600 juta, lebih tinggi dibanding capaian tahun 2018 yang sebesar US\$556,36 juta (Kementerian Perindustrian Republik Indonesia, 2020). Hal ini menjadi sebuah kabar baik bagi para produsen kosmetik merek lokal karena permintaan konsumen akan kosmetik merek lokal ini nyatanya masih mendominasi. Terlebih lagi, kini banyak bermunculan kosmetik merek lokal yang baru. Salah satunya adalah Make Over yang merupakan merek keluaran PT Paragon Technology and Innovation. Make Over diciptakan sebagai produk kosmetik dengan kualitas premium sehingga terkesan eksklusif. Walaupun masih tergolong baru, Make Over tercatat sudah menorehkan prestasi sejak 2017. Di awal tahun 2017, dua produk kosmetik dari Make Over, yaitu bedak tabur dan alas bedak, masuk ke dalam tiga produk kosmetik lokal teratas dengan raihan penilaian paling tinggi dari para anggota forum Female Daily (Aldasuwardi, 2017). Selain itu, dalam momen Female Daily Best of Beauty Awards di tahun 2017, 2018, dan 2019, produk Make Over selalu berhasil mendapatkan penghargaan, di antaranya pada kategori Best Liquid Lipstick di 2017 (Female Daily, 2017), lalu Best Contour/Shading di 2018 (Female Daily, 2018), dan yang terakhir Best Liquid Lipstick di 2019 (Female Daily, 2019).

Sederetan prestasi yang pernah diraih oleh Make Over inilah yang mengimplikasikan bahwa merek tersebut memiliki eksistensi yang sudah cukup diakui oleh banyak pengguna kosmetik di Indonesia meskipun masih terbilang sebagai produk baru. Hal ini juga yang akhirnya membuat peneliti tertarik dan ingin menelusuri lebih dalam terkait keputusan pembelian kosmetik merek Make Over. Salah satu aspek yang paling menarik perhatian dari merekmerek terkenal adalah kepribadian merek tersebut (Aaker, 1997). Kepribadian merek menurut Aaker (1997) merupakan sekumpulan karakteristik manusia yang diasosiasikan dengan merek. Menurut Tai \& Chew (2012), kepribadian adalah salah satu cara mendiferensiasi merek. Jika dieksekusi dengan baik, kepribadian merek yang kuat dan menarik dapat menjadi sumber diferensiasi dan kekuatan merek yang penting (Heding, Knudtzen, \& Bjerre, 2009). Konsumen juga menyetujui adanya konsep kepribadian merek, yakni mereka mengaitkan berbagai trait atau karakteristik kepribadian pada berbagai merek yang berbeda dalam kategori produk yang beragam pula (Schiffman \& Kanuk, 2010).

Pada beberapa penelitian sebelumnya, telah dilakukan pengujian pengaruh kepribadian merek terhadap keputusan pembelian konsumen, dimana hal ini menunjukkan adanya pengaruh yang signifikan (Andini \& Rahardjo, 2012), serta pengujian terhadap minat beli yang juga menunjukkan adanya pengaruh yang signifikan (Almanda, 2014). Dengan melekatkan kepribadian pada sebuah merek, hal ini akan meningkatkan daya tarik di hadapan konsumen (Vazifehdoost \& Hamedani, 2016).

Gupta (2013) mengungkapkan bahwa salah satu faktor yang dipertimbangkan oleh konsumen untuk membentuk persepsi positif terhadap suatu merek kosmetik adalah word of mouth. Terbentuknya persepsi yang positif terhadap suatu merek tentu bisa berlanjut ke arah minat untuk membeli dan berlanjut kepada keputusan pembelian. Rekomendasi dari pelanggan lain dianggap lebih terpercaya ketimbang promosi yang dilakukan oleh perusahaan dan dapat sangat memengaruhi keputusan orang lain untuk menggunakan (atau menghindari) suatu jasa (Lovelock, Wirtz, \& Mussry, 2010).

Seiring dengan perkembangan zaman dan datangnya era globalisasi, fenomena word of mouth kini berkembang menjadi electronic word of mouth (eWOM). Electronic word of mouth adalah pernyataan positif maupun negatif yang diberikan oleh pelanggan yang potensial, aktual, atau mantan pelanggan mengenai suatu produk atau perusahaan di mana 
pernyataan tersebut terbuka untuk banyak orang dan institusi melalui internet (Hennig-Thurau, Gwinner, Walsh, \& Gremler, 2004). Fenomena eWOM ini muncul ke permukaan dengan di latarbelakangi oleh kehadiran internet. Internet inilah yang akhirnya memfasilitasi eWOM.

Pada penelitian terdahulu, telah ditemukan bahwa eWOM berpengaruh secara signifikan terhadap keputusan pembelian (Park, Wang, Yao, \& Kang, 2011; Almana \& Mirza, 2013; Themba \& Mulala, 2013). Konsumen juga membutuhkan referensi untuk menguatkan keyakinan dalam mengurangi perasaan bersalah atau pengambilan resiko ketika berbelanja, serta kuantitas komentar yang tersedia secara online pun dapat menunjukkan popularitas dari produk tersebut (Lin, Wu, \& Chen, 2013).

Dari penjelasan tersebut, peneliti menyusun hipotesis penelitian sebagai berikut.

$\mathrm{H}_{1}$ : Electronic word of mouth berhubungan secara signifikan terhadap keputusan pembelian konsumen pada produk kosmetik merek lokal MAKE OVER.

$\mathrm{H}_{2}$ : Kepribadian merek berhubungan secara signifikan terhadap keputusan pembelian konsumen pada produk kosmetik merek lokal MAKE OVER.

$\mathrm{H}_{3}$ : Electronic word of mouth dan kepribadian merek berhubungan secara signifikan terhadap keputusan pembelian konsumen pada produk kosmetik merek lokal MAKE OVER.

\section{METODE}

Metode yang digunakan berupa metode penelitian kuantitatif. Subjek merupakan individu berjenis kelamin perempuan, berusia 20-34 tahun, berdomisili di Jabodetabek dan paling tidak telah membeli produk kosmetik merek MAKE OVER sebanyak satu kali. Peneliti menyebarkan kuesioner melalui bantuan google form melalui media sosial Facebook, Instastory, dan Whatsapp. Jumlah sampel yang terlibat dalam penelitian ini adalah sebanyak 439 responden.

eWOM akan diukur menggunakan alat ukur yang sudah diadaptasi dari Skala eWOM Jalilvand \& Samiei (2012) yang terdiri dari 6 item dengan nilai reliabilitas sebesar 0,87. Contoh itemnya adalah "Saya sering membaca review produk di media online untuk mengetahui produk/merek apa yang memiliki kesan yang baik". Untuk membaca seluruh itemnya dapat dilihat di Lampiran 1.

Kepribadian merek diukur menggunakan Skala Kepribadian Merek yang diadaptasi dari Rachmatianti (2014) yang terdiri dari 19 item dengan nilai reliabilitas sebesar 0,93. Contoh item alat ukur ini adalah "Menurut saya kosmetik merek MAKE OVER memiliki formula yang pas". Untuk membaca seluruh itemnya dapat dilihat di Lampiran 2

Sementara itu, keputusan pembelian diukur menggunakan 20 item yang diadaptasi dari Skala Keputusan Pembelian milik Branitasandhini (2017) dengan nilai reliabilitas sebesar 0,857. Untuk membaca seluruh itemnya dapat dilihat di Lampiran 3.

Ketiga alat ukur tersebut menggunakan Skala Likert dari 1 (sangat tidak sesuai) sampai 5 (sangat sesuai). Di dalam kuesioner yang disebar, terdapat pula pertanyaan yang harus diisi subjek untuk mengidentifikasi demografinya.

Confirmatory Factor Analysis (CFA) digunakan untuk menguji validitas, dan Composite Reliability untuk menguji reliabilitas. Dalam melakukan pengujian tersebut, digunakan software LISREL 8.70. Selanjutnya, software SPSS digunakan untuk uji analisis berganda.

\section{HASIL DAN PEMBAHASAN}

Data di Tabel 2 menunjukkan profil subjek berdasarkan usia, domisili, dan jenis pekerjaan. Dari 439 orang subjek yang diteliti, 344 orang $(78,4 \%)$ diantaranya berusia 20 - 24 tahun, 71 orang $(16,2 \%)$ diantaranya berusia 25 - 29 tahun, dan 24 orang $(5,5 \%)$ diantaranya berusia $30-34$ tahun. Hal ini menunjukkan bahwa sebagian besar responden dalam penelitian ini berusia antara 20 - 24 tahun. Kemudian jika dilihat dari domisili, sebagian besar subjek berdomisili di DKI Jakarta, yaitu sebanyak 200 orang $(45,6 \%)$. Pada jenis pekerjaan, sebagian besar responden adalah pelajar/mahasiswa, yaitu sebanyak 253 orang $(57,6 \%)$, kemudian pegawai swasta sebanyak 117 orang $(26,7 \%)$, dan sisanya memiliki pekerjaan lainnya.

Tabel 2. Profil Subjek

\begin{tabular}{lcc}
\hline \multicolumn{1}{c}{ Karakteristik } & $\mathrm{n}$ & $\%$ \\
\hline Usia & 344 & 78,4 \\
$20-24$ & 71 & 16,2 \\
$25-29$ & 24 & 5,5 \\
$30-34$ & & \\
& & \\
Domisili & 200 & 45,6 \\
DKI Jakarta & 23 & 5,2 \\
Bogor & 36 & 8,2 \\
Depok & 131 & 29,8 \\
Tangerang & 49 & 11,2 \\
Bekasi & & \\
& & \\
Jenis Pekerjaan & 253 & 57,6 \\
Pelajar/Mahasiswa & 117 & 26,7 \\
Pegawai Swasta & 11 & 2,5 \\
Pegawai Negeri & 23 & 5,2 \\
Wirausaha & 27 & 6,2 \\
Ibu Rumah & & \\
Tangga & 8 & 1,9 \\
Lainnya & & \\
\hline
\end{tabular}


Dalam pengujian CFA, item dapat dikatakan valid apabila estimasi koefisien bobot faktor yang distandarkan (standardized factor loading) tidak kurang dari 0,50 (Hair, dkk., 2006; Ghozali, 2004; Kusnendi, 2008). Berdasarkan hasil pengujian CFA, ditemukan beberapa item yang tidak valid pada tiap alat ukur. Pada alat ukur eWOM, terdapat 2 item yang tidak valid, 1 item alat ukur tidak valid pada kepribadian merek, dan 7 item alat ukur tidak valid pada keputusan pembelian. Hasil uji CFA tersebut dapat dilihat pada Tabel 3.

\section{Tabel 3. Uji CFA}

\begin{tabular}{|c|c|c|c|}
\hline Variabel & Dimensi & Item & $\begin{array}{c}\text { Factor } \\
\text { Loading }\end{array}$ \\
\hline \multirow{6}{*}{\multicolumn{2}{|c|}{$e W O M$}} & eWOM1 & 0,699 \\
\hline & & eWOM2 & 0,877 \\
\hline & & eWOM3 & 0,821 \\
\hline & & eWOM4 & 0,770 \\
\hline & & eWOM5 & 0,485 \\
\hline & & eWOM6 & 0,475 \\
\hline \multirow{19}{*}{$\begin{array}{l}\text { Kepribadia } \\
\text { n Merek }\end{array}$} & Sincerity & KM1 & 0,754 \\
\hline & & $\mathrm{KM} 2$ & 0,649 \\
\hline & & KM3 & 0,821 \\
\hline & & KM4 & 0,724 \\
\hline & Excitement & KM5 & 0,747 \\
\hline & & KM6 & 0,488 \\
\hline & & KM7 & 0,721 \\
\hline & & KM8 & 0,621 \\
\hline & & KM9 & 0,580 \\
\hline & Competence & KM10 & 0,796 \\
\hline & & KM11 & 0,778 \\
\hline & & KM12 & 0,694 \\
\hline & & KM13 & 0,765 \\
\hline & & KM14 & 0,744 \\
\hline & Sophisticati & KM15 & 0,529 \\
\hline & on & KM16 & 0,901 \\
\hline & Ruggedness & KM17 & 0,594 \\
\hline & & KM18 & 0,656 \\
\hline & & KM19 & 0,755 \\
\hline Keputusan & Pengenalan & KP1 & 0,379 \\
\hline \multirow[t]{16}{*}{ Pembelian } & Masalah & KP2 & 0,689 \\
\hline & & KP3 & 0,331 \\
\hline & Pencarian & KP4 & 0,445 \\
\hline & Informasi & KP5 & 0,816 \\
\hline & & KP6 & 0,803 \\
\hline & & KP7 & 0,471 \\
\hline & & KP8 & 0,709 \\
\hline & Evaluasi & KP9 & 0,556 \\
\hline & & KP10 & 0,699 \\
\hline & & KP11 & 0,767 \\
\hline & Keputusan & KP12 & 0,457 \\
\hline & Pembelian & KP13 & 0,732 \\
\hline & & KP14 & 0,641 \\
\hline & & KP15 & 0,615 \\
\hline & & KP16 & 0,659 \\
\hline & & KP17 & 0,790 \\
\hline
\end{tabular}

\begin{tabular}{lll} 
Perilaku & KP18 & 0,328 \\
Pasca & KP19 & 0,788 \\
Pembelian & KP20 & 0,069 \\
\hline
\end{tabular}

Setelah ditemukan adanya item-item yang tidak valid, maka dilakukan reduksi terhadap item-item yang tidak valid tersebut dan selanjutnya dilakukan pengujian CFA kembali. Pada pengujian CFA ini, ditemukan bahwa seluruh item memiliki nilai factor loading $>0,5$, sehingga dapat dikatakan valid.

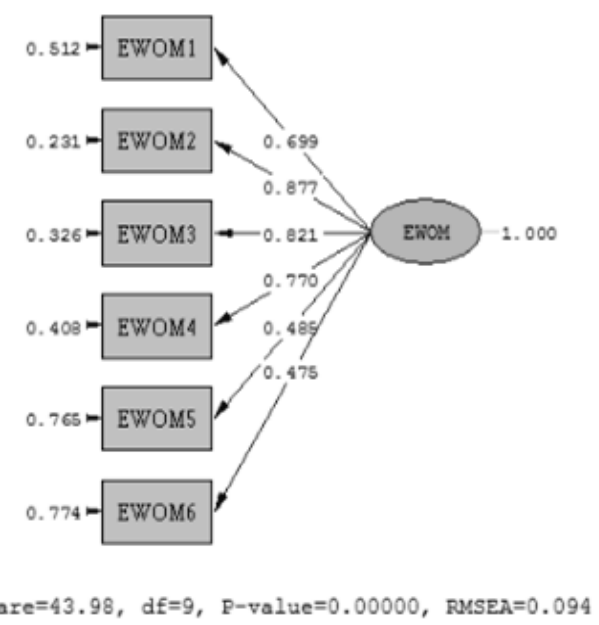

Gambar 1. Uji Konfirmatori Variabel eWOM (Standardized)

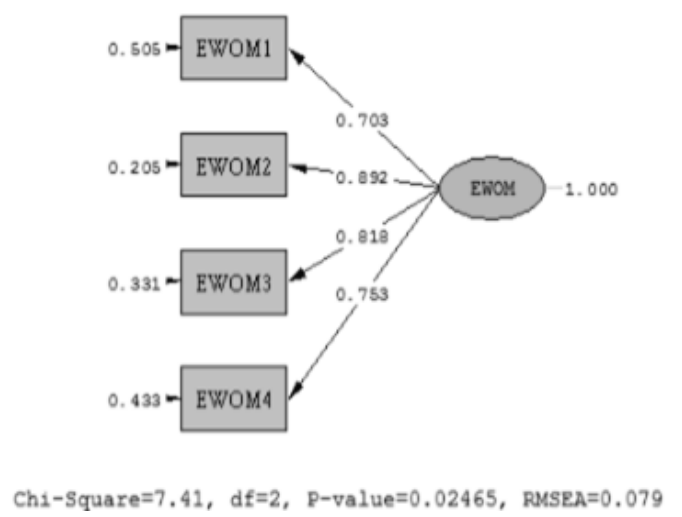

\section{Gambar 2. Uji Konfirmatori Variabel eWOM (Standardized) Setelah Reduksi}

Berdasarkan Tabel 4, dapat diketahui hasil pengujian variabel eWOM yang menunjukan bahwa semua itemnya memiliki loading factor diatas 0,5, sehingga semua item sudah valid dalam mengukur variabel latennya. Berdasarkan nilai $\mathrm{CR}$, terlihat bahwa konstruk laten memiliki nilai $\mathrm{CR}>0,7$ dan nilai $\mathrm{VE}>0,5$, sehingga dianggap reliabel. Hal ini menunjukkan bahwa item-item tersebut memiliki kekonsistenan dalam mengukur variabel eWOM. Untuk Uji CFA variabel eWOM dapat dilihat di Gambar 1 dan 2. 


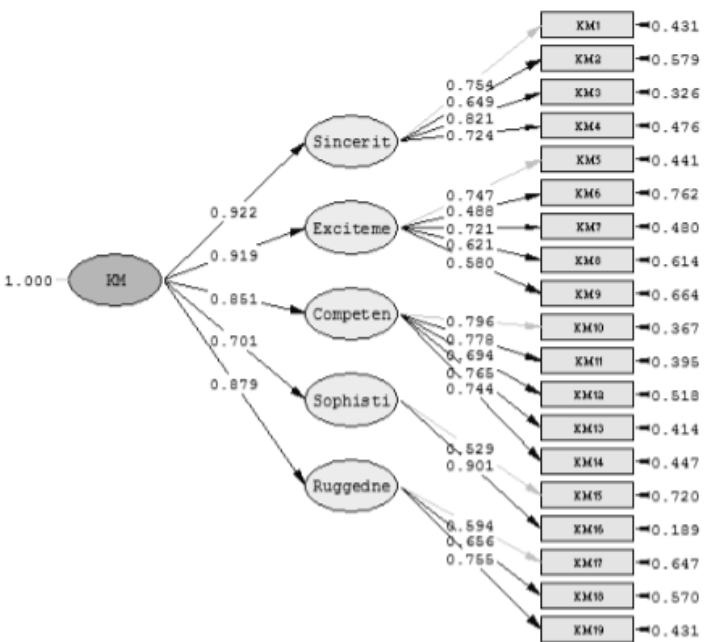

Chi-Square $=668.68, d f=147, p-$ value $=0.00000$, RMSEA $=0.090$

Gambar 3. Uji Konfirmasi Variabel Kepribadian Merek (Standardized)

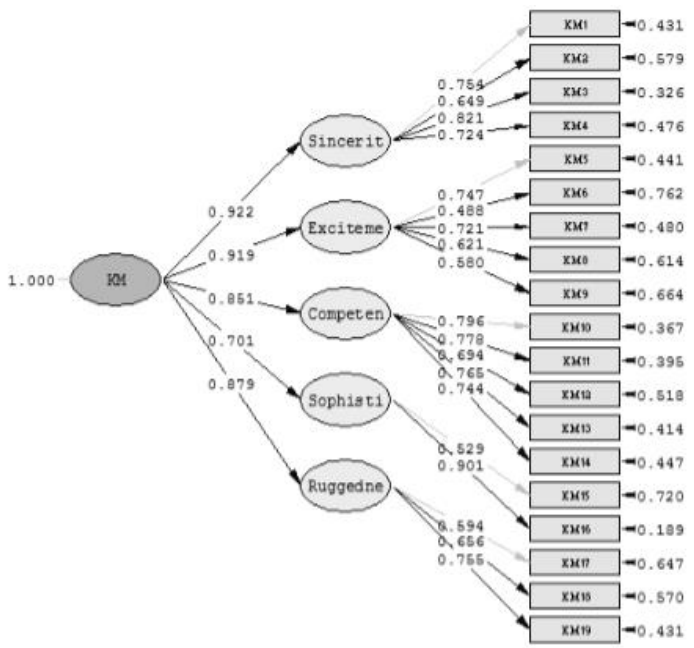

Chi-Square $=668.68, d f=147, p-$ value $=0.00000$, RMSEA $=0.090$

Gambar 4. Uji Konfirmasi Variabel Kepribadian Merek (Standardized) Setelah Reduksi

Tabel 4. Pengujian Standardized dan Unstandardized Coefficients

\begin{tabular}{ccccccc}
\hline Observed variable & Latent construct & $\boldsymbol{\beta}$ & B & SE & CR & VE \\
\hline EWOM1 & EWOM & 0,703 & 0,497 & 0,031 & 0,87 & 0,63 \\
EWOM2 & EWOM & 0,892 & 0,625 & 0,028 & & \\
EWOM3 & EWOM & 0,818 & 0,563 & 0,028 & & \\
EWOM4 & EWOM & 0,753 & 0,555 & 0,031 & & \\
\hline
\end{tabular}

Tabel 5. Pengujian Standardized dan Unstandardized Coefficients

\begin{tabular}{|c|c|c|c|c|c|c|}
\hline Observed variable & Latent construct & B & B & SE & CR & VE \\
\hline \multirow[t]{4}{*}{ Sincerity } & KM1 & 0,754 & 0,552 & - & 0,83 & 0,55 \\
\hline & KM2 & 0,65 & 0,515 & 0,039 & & \\
\hline & KM3 & 0,821 & 0,703 & 0,041 & & \\
\hline & KM4 & 0,723 & 0,512 & 0,034 & & \\
\hline \multirow[t]{4}{*}{ Excitement } & KM5 & 0,729 & 0,615 & - & 0,76 & 0,44 \\
\hline & KM7 & 0,711 & 0,618 & 0,045 & & \\
\hline & KM8 & 0,621 & 0,465 & 0,038 & & \\
\hline & KM9 & 0,58 & 0,545 & 0,048 & & \\
\hline \multirow[t]{5}{*}{ Competence } & KM10 & 0,796 & 0,569 & - & 0,87 & 0,57 \\
\hline & KM11 & 0,777 & 0,597 & 0,035 & & \\
\hline & KM12 & 0,695 & 0,488 & 0,032 & & \\
\hline & KM13 & 0,765 & 0,553 & 0,033 & & \\
\hline & KM14 & 0,744 & 0,479 & 0,029 & & \\
\hline \multirow[t]{2}{*}{ Sophistication } & KM15 & 0,526 & 0,498 & - & 0,69 & 0,55 \\
\hline & KM16 & 0,905 & 0,865 & 0,106 & & \\
\hline \multirow[t]{3}{*}{ Ruggedness } & KM17 & 0,592 & 0,542 & - & 0,70 & 0,45 \\
\hline & KM18 & 0,657 & 0,586 & 0,057 & & \\
\hline & KM19 & 0,756 & 0,599 & 0,053 & & \\
\hline
\end{tabular}




\begin{tabular}{|c|c|c|c|c|c|c|}
\hline Second Order & & & & & & \\
\hline Kepribadian Merek & Sincerity & 0,923 & 0,923 & 0,057 & 0,93 & 0,74 \\
\hline & Excitement & 0,942 & 0,942 & 0,060 & & \\
\hline & Competence & 0,852 & 0,852 & 0,053 & & \\
\hline & Sophistication & 0,696 & 0,696 & 0,093 & & \\
\hline & Ruggedness & 0,876 & 0,876 & 0,077 & & \\
\hline
\end{tabular}

Sumber: Hasil olah data primer, 2018

Berdasarkan Tabel 5, dapat diketahui hasil pengujian variabel kepribadian merek dengan model second order yang menunjukan bahwa pada first order, terlihat semua indikatornya memiliki loading factor di atas 0,5, sehingga semua indikator sudah valid dalam mengukur masing-masing dimensi. Pada second order, terlihat semua dimensi memiliki loading factor di atas 0,5 sehingga semua dimensi sudah valid dalam mengukur variabel kepribadian merek. Dilihat dari nilai $\mathrm{CR}$, terlihat bahwa semua konstruk laten memiliki nilai $\mathrm{CR}>0,7$ dan nilai $\mathrm{VE}$ mendekati 0,5, sehingga dianggap reliabel. Hal ini menunjukkan bahwa indikator-indikator tersebut memiliki kekonsistenan dalam mengukur masingmasing konstruk latennya. Berdasarkan hasil pengujian CFA di Gambar 3 dan 4, diketahui bahwa indikator yang diteliti sudah valid dan reliabel, sehingga dapat dilanjutkan untuk pengujian selanjutnya.

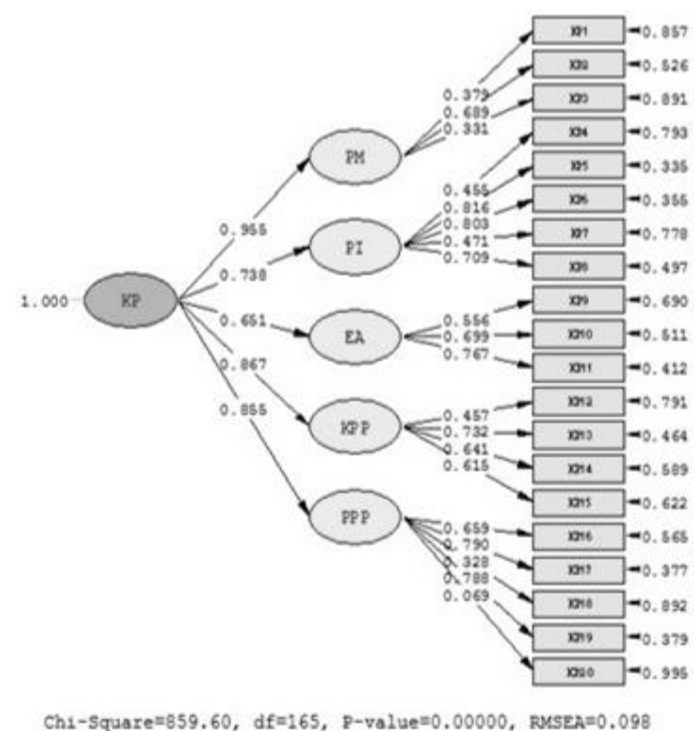

Gambar 5. Uji Konfirmasi Variabel Keputusan Pembelian (Standardized)

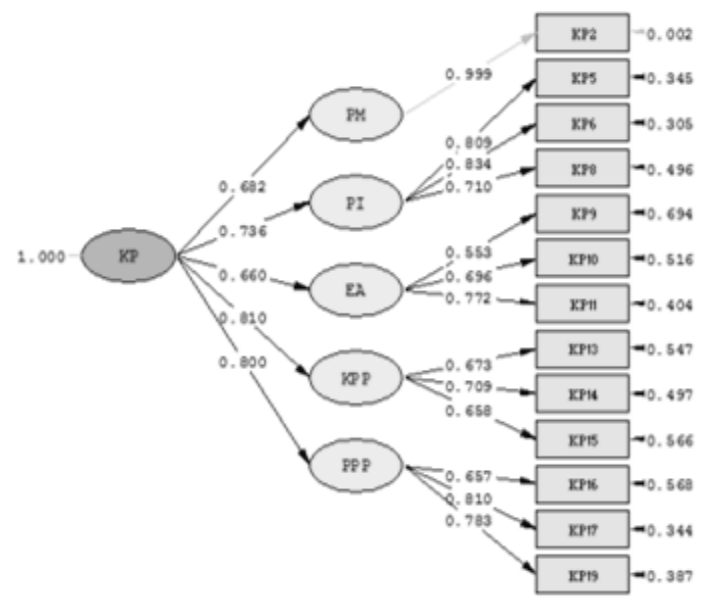

Ch1-Square $=298.15, d f=61, p$-value $=0.00000$, RMSEA $=0.094$

Gambar 6. Uji Konfirmasi Variabel Keputusan Pembelian (Standardized) Setelah Reduksi

Tabel 6. Pengujian Standardized dan Unstandardized Coefficients

\begin{tabular}{|c|c|c|c|c|c|c|}
\hline Observed variable & Latent construct & B & B & SE & CR & VE \\
\hline \multicolumn{7}{|c|}{ First Order } \\
\hline KP2 & PM & 0,999 & 0,778 & - & 0,998 & 0,998 \\
\hline KP5 & PI & 0,809 & 0,430 & 0,030 & 0,829 & 0,618 \\
\hline KP6 & PI & 0,834 & 0,380 & 0,030 & & \\
\hline KP8 & PI & 0,710 & 0,400 & 0,031 & & \\
\hline
\end{tabular}




\begin{tabular}{ccccccc} 
KP9 & EA & 0,553 & 0,371 & 0,037 & 0,717 & 0,462 \\
KP10 & EA & 0,696 & 0,473 & 0,039 & & \\
KP11 & EA & 0,772 & 0,484 & 0,038 & & \\
KP13 & KPP & 0,673 & 0,324 & 0,036 & 0,721 & 0,463 \\
KP14 & KPP & 0,709 & 0,319 & 0,034 & & \\
KP15 & KPP & 0,658 & 0,341 & 0,038 & & \\
KP16 & PPP & 0,657 & 0,341 & 0,033 & 0,796 & 0,567 \\
KP17 & PPP & 0,810 & 0,359 & 0,031 & & \\
KP19 & PPP & 0,783 & 0,370 & 0,032 & & \\
\hline & SM & 0,682 & 0,682 & 0,047 & 0,857 & 0,548 \\
\hline KP & PI & 0,736 & 1,088 & 0,114 & & \\
& EA & 0,660 & 0,879 & 0,103 & & \\
& KPP & 0,810 & 1,381 & 0,182 & & \\
\hline & PPP & 0,800 & 1,332 & 0,153 & & \\
& Second Order
\end{tabular}

Sumber: Hasil olah data primer, 2018

Berdasarkan Tabel 6, dapat diketahui hasil pengujian variabel keputusan pembelian pada first order yang menunjukkan bahwa semua itemnya memiliki loading factor di atas 0,5, sehingga semua item sudah valid dalam mengukur masing-masing dimensi. Pada second order, terlihat semua dimensi memiliki loading factor di atas 0,5, sehingga semua dimensi sudah valid dalam mengukur variabel keputusan pembelian. Dilihat dari nilai CR, terlihat bahwa semua konstrak laten memiliki nilai CR > 0,7 dan nilai VE mendekati 0,5 , sehingga dianggap reliabel. Hal ini menunjukkan bahwa item-item tersebut memiliki kekonsistenan dalam mengukur masing-masing konstruk latennya. Berdasarkan hasil pengujian CFA di Gambar 5 dan 6, diketahui bahwa item yang diteliti sudah valid dan reliabel, sehingga dapat dilanjutkan untuk pengujian selanjutnya.

Hasil analisis regresi variabel eWOM dan kepribadian merek terhadap keputusan pembelian dengan software SPSS 20 dapat dilihat pada Tabel 7.

Tabel 7. Hasil Analisis Regresi Variabel $e$ WOM dan Kepribadian Merek terhadap Keputusan Pembelian

\begin{tabular}{lccc}
\hline \multicolumn{1}{c}{ Variable } & $\boldsymbol{R}$ & $\begin{array}{c}\boldsymbol{R} \\
\text { Square }\end{array}$ & $\begin{array}{c}\text { Adjusted } \\
\boldsymbol{R} \text { Square }\end{array}$ \\
\hline $\begin{array}{l}\text { eWOM (X1) \& } \\
\text { Kepribadian Merek } \\
\text { (X2) }\end{array}$ & 0,754 & 0,569 & 0,567 \\
\hline
\end{tabular}

Korelasi signifikan pada 0,05

Berdasarkan hasil pada Tabel 7, dapat diketahui nilai $R$ square sebesar 0,569 atau $56,9 \%$. Hal ini menunjukan bahwa variabel electronic word of mouth (X1) dan kepribadian merek (X2) berpengaruh sebesar $56,9 \%$ terhadap keputusan pembelian (Y), sedangkan sisanya, yaitu sebesar $43,1 \%$, dipengaruhi oleh faktor lain yang tidak diteliti.

\section{Uji Hipotesis}

Hipotesis pertama berbunyi electronic word of mouth berkontribusi secara signifikan terhadap keputusan pembelian konsumen pada produk kosmetik merek lokal "MAKE OVER". Berikut ini disajikan hasil uji signifikansi dari hipotesis tersebut melalui hipotesis statistik sebagai berikut.

Tabel 8. Hasil Pengujian Hubungan Electronic Word of Mouth terhadap Keputusan Pembelian

\begin{tabular}{cccc}
\hline $\begin{array}{c}\text { Koef. } \\
\text { Regresi }\end{array}$ & thitung & Sig & $\mathbf{H}_{\mathbf{1}}$ \\
\hline 0,322 & 11,461 & $0,000^{*}$ & Diterima \\
\hline
\end{tabular}

Catatan: *p $<0,05$

Berdasarkan Tabel 8, dapat dilihat nilai $t_{\text {hitung }}$ variabel electronic word of mouth sebesar 11,461 dan nilai sig. sebesar 0,000. Dikarenakan nilai $t_{\text {hitung }}$ $(11,461)>t_{\text {tabel }}(1,965)$ dan nilai sig $0,000<0,05$, maka pada tingkat kekeliruan $5 \%$ diputuskan untuk menolak $H_{0}$ dan menerima $H_{l}$, sehingga hipotesis pertama diterima. Berdasarkan hasil pengujian, maka dapat disimpulkan bahwa electronic word of mouth berhubungan secara signifikan terhadap keputusan pembelian konsumen pada produk kosmetik merek lokal MAKE OVER.

Hipotesis kedua pada penelitian ini berbunyi bahwa kepribadian merek berkontribusi secara signifikan terhadap keputusan pembelian konsumen pada produk kosmetik merek lokal MAKE OVER. Berikut ini disajikan hasil uji signifikansi dari hipotesis tersebut melalui hipotesis statistik sebagai berikut.

Tabel 9. Hasil Pengujian Hubungan Kepribadian Merek terhadap Keputusan Pembelian

\begin{tabular}{cccc}
\hline $\begin{array}{c}\text { Koef. } \\
\text { Regresi }\end{array}$ & thitung & Sig. & $\mathbf{H}_{2}$ \\
\hline 0,533 & 16,868 & $0,000 *$ & Diterima \\
\hline
\end{tabular}

Catatan: $* \mathrm{p}<0,05$ 
Berdasarkan Tabel 9, dapat dilihat nilai $\mathrm{t}_{\text {hitung }}$ variabel kepribadian merek sebesar 16,868 dan nilai sig. sebesar 0,000. Dikarenakan nilai thitung $(16,868)>$ $\mathrm{t}_{\text {tabel }}(1,965)$ dan nilai sig. $0,000<0,05$, maka pada tingkat kekeliruan 5\% diputuskan untuk menolak $H_{0}$ dan menerima $H_{2}$, sehingga hipotesis kedua diterima. Berdasarkan hasil pengujian, maka dapat disimpulkan bahwa kepribadian merek berhubungan secara signifikan terhadap keputusan pembelian konsumen pada produk kosmetik merek lokal MAKE OVER.

Hipotesis secara simultan (Uji F) dilakukan untuk mengetahui apakah semua variabel electronic word of mouth dan kepribadian merek secara bersama-sama berkontribusi terhadap keputusan pembelian konsumen pada produk kosmetik merek lokal MAKE OVER, di mana pengujian hipotesis pada penelitian ini adalah sebagai berikut:

Berdasarkan pengolahan data menggunakan SPSS 20, maka diperoleh output seperti pada Tabel 10 berikut ini.

\section{Tabel 10. Hasil Uji Simultan (Uji F)}

\begin{tabular}{cc} 
ANOVA $^{\mathbf{a}}$ & \\
\hline Uji F & Sig. \\
\hline 287,302 & $0,000^{*}$
\end{tabular}

\section{Catatan: *p $<0,05$}

Variabel Dependen: Keputusan Pembelian Varibabel Independen: Kepribadian Merek, Electronic Word of Mouth

Berdasarkan taraf signifikansi $\alpha=0,05$ maka diperoleh nilai $F_{\text {tabel }}$ sebesar 287,302 dan nilai sig. sebesar 0,000. Dari hasil perhitungan pada tabel ANOVA di atas, diketahui nilai $F_{\text {hitung }}(287,302)>$ $F_{\text {tabel }}(3,016)$ dan nilai sig. $0,000<0,05$, sehingga pada tingkat kekeliruan 5\% diputuskan untuk menolak $H_{0}$ dan menerima $H_{3}$ sehingga hipotesis ketiga diterima. Berdasarkan hasil pengujian, maka dapat disimpulkan bahwa electronic word of mouth dan kepribadian merek berpengaruh secara signifikan terhadap keputusan pembelian konsumen pada produk kosmetik merek lokal MAKE OVER.

Hasil pengujian model struktural keseluruhan dapat dilihat di Gambar 7 berikut ini.

Dari Gambar 7 dan Gambar 8 dapat dilihat bahwa variabel kepribadian merek competence merupakan variabel yang memberikan sumbangsih terbesar dan signifikan terhadap keputusan pembelian pada merek MAKE OVER.

Dalam penelitian ini, ditemukan bahwa baik secara terpisah dan bersamaan, eWOM dan kepribadian merek memiliki peran yang signifikan terhadap keputusan pembelian. Dalam kaitannya dalam eWOM, konsumen masih lebih memercayakan review produk yang dituliskan oleh konsumen lainnya

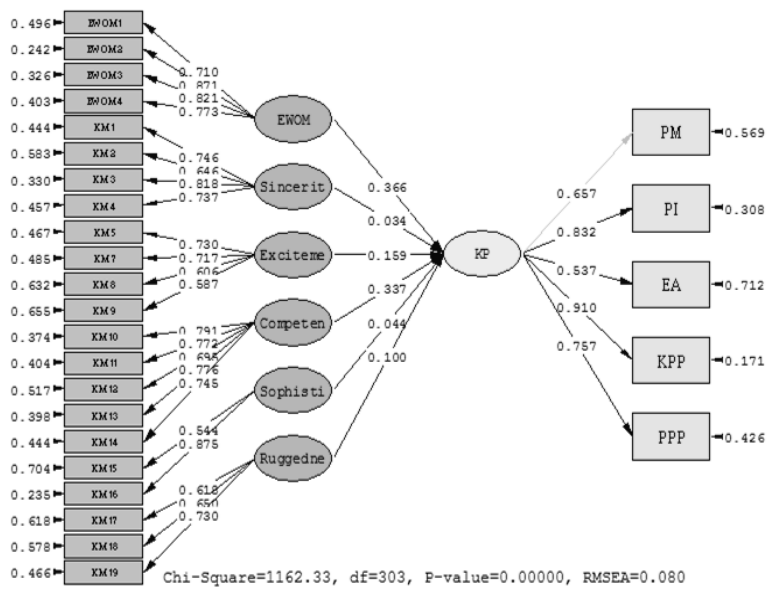

\section{Gambar 7. Hasil Full Model Struktural (Standarized)}

Untuk mendalami variabel kepribadian merek yang signifikan terhadap keputusan pembelian dilakukan uji T kepada seluruh variabel kepribadian merek dan eWOM terhadap keputusan pembelian. Hasilnya dapat dilihat pada Gambar 8.

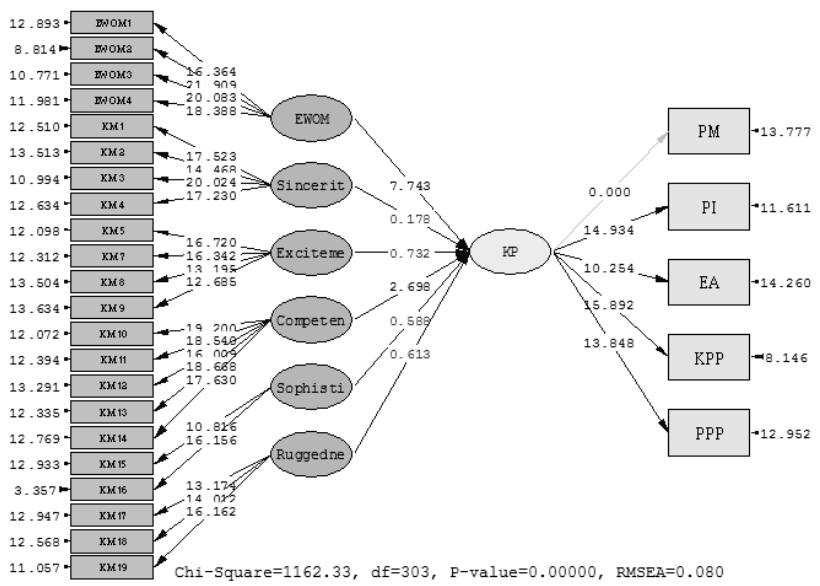

Gambar 8. Hasil Full Model Struktural Modifikasi (T values)

di media online, sehingga review produk yang telah dibaca dapat membantu konsumen dalam mengevaluasi produk sebelum selanjutnya membuat keputusan pembelian.

Hasil penelitian ini menunjukkan bahwa eWOM memiliki pengaruh sebesar 32,2\% terhadap keputusan pembelian. Hal ini dikarenakan eWOM mempunyai beberapa syarat untuk dapat memengaruhi keputusan pembelian, yaitu pemilihan media (Djafarova \& Rushworth, 2017), serta kredibilitas dari penyebar dan isi pembicaraan (Moran \& Muzellec, 2014).

Penelitian yang dilakukan juga menunjukkan bahwa kepribadian merek berpengaruh terhadap 
keputusan pembelian sebesar 53\%, yangmana lebih besar dibandingkan eWOM. Hal ini dikarenakan dalam penelitian sebelumnya, kepribadian merek mempunyai pengaruh langsung kepada keputusan pembelian, serta pengaruh tidak langsung kepada keputusan pembelian melalui variabel moderasi keterikatan terhadap merek (brand engagement) (Lee, Hansen, \& Lee, 2018).

Cheung, Xiao, dan Liu (2012) mengungkapkan bahwa hubungan antara eWOM dengan penjualan produk dapat dijelaskan baik melalui awareness effect ataupun persuasive effect. Awareness effect menunjukkan bahwa semakin banyak jumlah eWOM yang ada, maka product awareness akan semakin meningkat, yang selanjutnya akan menghasilkan penjualan produk yang meningkat pula. Sementara itu, persuasive effect dapat membentuk evaluasi konsumen terhadap suatu produk yang pada akhirnya memengaruhi keputusan pembeliannya. Dengan kata lain, komunikasi eWOM memiliki peran yang begitu penting dalam keputusan pembelian karena dapat meningkatkan kesadaran konsumen mengenai suatu produk, yang selanjutnya dapat berperan dalam proses pembentukan keputusan pembelian konsumen. Pada studi lainnya, ditemukan bahwa penilaian yang tinggi dan karakteristik dari review produk yang ada menjadi faktor yang efektif dalam membuat keputusan pembelian (Almana \& Mirza, 2013).

Hasil dari pengujian terkait peran kepribadian merek terhadap keputusan pembelian dalam penelitian ini pun sejalan dengan hasil penelitian yang dilakukan oleh Andini dan Rahardjo (2012), bahwa kepribadian merek memiliki peran yang signifikan terhadap keputusan pembelian. Hal ini dapat dikarenakan konsumen lebih memilih merek yang memiliki kepribadian yang mendekati citra diri mereka sendiri, baik itu desired self image atau actual self image (Vazifehdoost \& Hamedani, 2016). Dengan demikian, dapat dikatakan bahwa Make Over memiliki kepribadian merek yang berpengaruh pada konsumennya. Ini berarti sebagai merek kosmetik lokal, produsen Make Over mampu membangun merek yang mempunyai ikatan emosional dan identitas kepribadian tertentu dengan konsumennya. Konsumen merasa merek produk kosmetik Make Over menggambarkan diri mereka dalam simbol dan makna tertentu.

Adanya peran kepribadian merek ini menunjukkan bahwa kepribadian merek yang dimiliki Make Over terasosiasi dengan karakteristik tertentu yang diinginkan oleh konsumen. Hal ini sesuai dengan pendapat Aaker (1997) bahwa kepribadian merek adalah karakteristik tertentu yang ditangkap konsumen terhadap merek produk tertentu. Berdasarkan penelitian yang dilakukan oleh Zhang (2017), diketahui bahwa kepribadian merek, khususnya pada dimensi sincerity, excitement, dan competence, memiliki pengaruh terhadap keputusan pembelian. Hal ini menunjukkan bahwa merek produk ditentukan dari sejauh mana konsumen merasa produk tersebut dapat membuat mereka menjadi seseorang yang dapat diandalkan, dapat dipercaya, membumi, unik, bersemangat, kekinian, dan menarik.

Hasil penelitian terhadap merek lokal Make Over di Indonesia ini menguatkan temuan bahwa kepribadian merek memberikan pengaruh terhadap keputusan pembelian konsumen. Berdasarkan Gambar 8, kepribadian merek competence memiliki sumbangan pengaruh paling tinggi terhadap keputusan pembelian. Hal yang membedakan dengan penelitian Zhang (2017) adalah pada penelitian ini, ketika dilakukan uji masing masing dimensi kepribadian merek terhadap keputusan pembelian, terdapat satu dimensi kepribadian merek yang memberikan sumbangsih terbesar dan paling signifikan, yaitu dimensi kepribadian merek competence. Hal ini berarti konsumen membeli produk merek Make Over untuk mengalami identitas kepribadian sebagai orang yang mempunyai keterandalan, sukses, cerdas, dan dipercaya oleh banyak orang.

Hasil penelitian juga memperlihatkan bahwa eWOM dan kepribadian merek merupakan hal yang penting dalam memengaruhi keputusan pembelian konsumen saat ini. Hal ini dikarenakan konsumen saat ini memilih untuk melihat review produk melalui situs online atau media sosial. Pernyataan Becheur, Bayarassou, \& Ghrib (2017) pun menguatkan bahwa kepribadian merek yang dibangun melalui review secara online (eWOM) dalam situs media sosial seperti Facebook memiliki pengaruh yang menguatkan komitmen konsumen dalam membeli produk merek tersebut.

Penelitian ini juga memberikan sumbangsih dalam konteks Indonesia bahwa kepribadian merek memiliki pengaruh penting dalam membangun keputusan pembelian. Penelitian sebelumnya dalam konteks India memperlihatkan pentingnya kepribadian merek, khususnya pada dimensi sincerity, excitement, competence, dan ruggedness (Srivastava \& Sharma, 2016). Dalam konteks Indonesia, khususnya pada merek lokal Make Over, jika setiap komponen diuji secara keseluruhan sebagai satu model, maka akan memiliki efek yang cukup tinggi dalam membangun kepribadian merek seperti yang ditunjukkan dalam Tabel 6.

Pada penelitian ini pun diperoleh hasil bahwa eWOM memiliki pengaruh terhadap keputusan pembelian, yang mana juga sejalan dengan penelitian terbaru di Iran. Pada penelitian di Iran, diperoleh hasil yang menunjukkan bahwa eWOM memiliki pengaruh pada tingkah laku pembelian (Farzin \& Fattahi, 2018). Hasil dari penelitian ini dapat menjadi langkah awal untuk penelitian mengenai eWOM terhadap tingkah laku pembelian dalam konteks Indonesia.

Dalam penelitian ini, sub kepribadian merek competence merupakan sub kepribadian merek yang paling signifikan dan berpengaruh terhadap keputusan pembelian khususnya di produk kosmetik lokal Make 
Over. Hal ini menunjukkan pentingnya memperhatikan aspek competence dalam membangun kepribadian merek, khususnya pada merek produk kosmetik. Aspek kepribadian merek competence adalah identitas merek yang membuat konsumen merasa menjadi orang yang cerdas, sukses, handal, dan dapat dipercaya, ketika membeli atau memakai produk tersebut.

\section{SIMPULAN}

Electronic word of mouth dan kepribadian merek berperan secara signifikan terhadap keputusan pembelian konsumen pada kosmetik merek lokal Make Over. Hal ini berarti produsen merek lokal perlu membangun kepribadian merek yang kuat dan membuat kampanye di media daring yang efektif. Kampanye media daring yang efektif adalah ketika produsen merek lokal mampu membangun identitas emosional yang kuat terhadap merek tersebut sehingga dibicarakan secara viral dari mulut ke mulut.

Penelitian ini memperlihatkan bahwa dimensi kepribadian merek yang berperan signifikan dalam keputusan pembelian adalah dimensi kepribadian merek competence. Kepribadian merek competence memberikan identitas emosional pada pemakai sebagai kumpulan orang yang memiliki identitas dapat dipercaya, tangguh, dan dapat diandalkan. Hal ini menunjukkan pentingnya produsen produk kosmetik lokal membuat produk yang mempunyai kepribadian merek kuat khususnya pada dimensi kepribadian merek competence disertai dengan kampanye media daring yang efektif. Kampanye media daring yang efektif memuat pesan produk yang informatif, ulasan yang memadai dari konsumen, dan testimoni positif. Produk kosmetik lokal dengan kepribadian merek yang kuat disertai dengan pembicaraan mulut ke mulut yang positif di media daring akan membuat konsumen yakin dalam membuat keputusan pembelian.

Penelitian selanjutnya dapat membahas mengenai pengaruh kepribadian merek terhadap electronic word of mouth. Untuk mengetahui apakah kepribadian merek yang kuat dapat mempengaruhi konsumen untuk melakukan pembicaraan dan ulasan yang positif terhadap suatu produk di media daring.

\section{KETERBATASAN PENELITIAN}

Adapun beberapa keterbatasan penelitian yang dialami oleh peneliti dalam meneliti peran electronic word of mouth (eWOM) dan kepribadian merek yang dilihat melalui peran setiap dimensinya (sincerity, excitement, competence, sophistication, dan ruggedness) terhadap keputusan pembelian konsumen pada kosmetik merek lokal MAKE OVER adalah sebagai berikut:

- Media electronic word of mouth (eWOM) atau review produk pada penelitian ini bersifat umum dan tidak difokuskan pada media daring tertentu (seperti forum media daring, media sosial, laman berita, narablog, mesin pencari, dan kicauan).

- Wilayah penelitian hanya dilakukan di wilayah Jakarta, Bogor, Depok, Tangerang, dan Bekasi. Metode penelitian yang digunakan adalah metode kuantitatif, sehingga sumber data primer hanya sebatas dari kuesioner online dan offline.

\section{DAFTAR PUSTAKA}

Aaker, J. L. (1997). Dimensions of Brand Personality. Journal of Marketing Research, 34(3), 347-356.

Aldasuwardi. (2017). \#FDInsight: Makeup Lokal Indie Belum Kalahkan Pemain Lama. Diambil dari Female Daily: https://femaledaily.com/blog/2017/02/08/fdinsight-makeup-lokal/

Almana, A. M., \& Mirza, A. A. (2013). The Impact of Electronic Word of Mouth on Consumers , Purchasing Decisions. International Journal of Computer Applications, 82(9), 23-31.

Almanda, M. I. (2014). Pengaruh Brand Personality Sepatu Nike terhadap Minat Beli (Studi Kasus pada Mahasiswa Fakultas Komunikasi dan Bisnis, Universitas Telkom). Universitas Telkom.

Andini, P., \& Rahardjo, S. T. (2012). Analisis FaktorFaktor yang Mempengaruhi Keputusan Pembelian Mobil Hyundai i20. Diponegoro Journal of Management, 1(4), 105-116,.

Becheur, I., Bayarassou, O., \& Ghrib, H. (2017). Beyond Brand Personality: Building ConsumerBrand Emotional Relationship. Global Business Review, 18(4), 1-17. https://doi.org/10.1177/0972150917693160

Branitasandhini, Dhara K. (2017). Pengaruh Tipe Kepribadian "Big Five" dan Citra Merek terhadap Keputusan Pembelian Tiket Maskapai Garuda Indonesia di Indonesia. Universitas Mercu Buana Jakarta.

Cheung, C. M. K., Xiao, B., \& Liu, I. L. B. (2012). The Impact of Observational Learning and Electronic Word of Mouth on Consumer Purchase Decisions: The Moderating Role of Consumer Expertise and consumer Involvemen. 2012 45th Hawaii International Conference on System Sciences, 3228-3237. Maui.

Djafarova, E., \& Rushworth, C. (2017). Exploring the credibility of online celebrities' Instagram profiles in influencing the purchase decisions of young female users. Computers in Human Behavior, 68, 1-7.

Farzin, M., \& Fattahi, M. (2018). eWOM through social networking sites and impact on purchase intention and brand image in Iran. Journal of Advances in Management Research, 15(3), 161183.

Female Daily. (2017). Best of Beauty Awards Winners. Diambil kembali dari Female Daily: http://awards.femaledaily.com/winner/makeup20 
17

Female Daily. (2018). Best of Beauty Awards Winners. Diambil kembali dari Female Daily: http://awards.femaledaily.com/winner/makeup20 18

Female Daily. (2019). Best of Beauty Awards Winners. Diambil kembali dari Female Daily: http://awards.femaledaily.com/\#winners-detail$\underline{\text { boba }}$

Ghozali, I. (2004). Model Persamaan Struktural Konsep dan Aplikasi dengan AMOS Ver. 5.0. Semarang: Badan Penerbit Universitas Diponegoro.

Gupta, V. (2013). A Study on Consumer Perception and Brand Personality Traits for Making Cosmetics Purchase Decisions. Journal of Management, 5(1), 1-22.

Guthrie, M., Kim, H.-S., \& Jung, J. (2008). The Effects of Facial Image and Cosmetic Usage on Perceptions of Brand Personality. Journal of Fashion Marketing and Management, 12(2), 164-181.

Hair, J. F., Black, B., Babin, B., Anderson, R. E., \& Tatham, R. L. (2005). Multivariate Data Analysis (6th ed.). Upper Saddle River, NJ: Pearson Education.

Heding, T., Knudtzen, C. F., \& Bjerre, M. (2009). Brand Management: Research, Theory, and Practice. Routledge.

Hennig-Thurau, T., Gwinner, K. P., Walsh, G., \& Gremler, D. D. (2004). lectronic Word-of-Mouth via Consumer-Opinion platforms: What Motivates Consumers to Articulate Themselves on The Internet. Journal of Interactive Marketing, 18(1), 38-52.

Kementerian Perindustrian Republik Indonesia (2020). Perubahan Gaya Hidup Dorong Industri Kosmetik. Retrieved from https://www.kemenperin.go.id/artikel/21460/Per ubahan-Gaya-Hidup-Dorong-Industri-Kosmetik

Jalilvand, M. R., \& Samiei, N. (2012). The Effect of Electronic Word of Mouth on Brand Image and Purchase Intention. Marketing Intelligence \& Planning, 30(4), 460-476.

Kusnendi. (2008). Model-Model Persamaan Struktural: Satu dan Multigroup Sampel dengan LISREL. Bandung: Alfabeta.

Lee, J. K., Hansen, S. S., \& Lee, S.-Y. (2018). The effect of brand personality self-congruity on brand engagement and purchase intention: The moderating role of self-esteem in Facebook. Current Psychology, 1-13.

Lin, C., Wu, Y.-S., \& Chen, J. V. (2013). Electronic Word-of Mouth: The Moderating Roles of Product Involvement and Brand Image. 2013 International Conference on Technology and Industrial Management. Phuket.

Lovelock, C., Wirtz, J., \& Mussry, J. (2010). Services Marketing: People, Technology, Strategy [Pemasaran Jasa: Manusia, Teknologi, Strategi Perspektif Indonesia] (7th ed., Vol. 1). Jakarta: Erlangga.

Moran, G., \& Muzellec, L. (2014). eWOM credibility on social networking sites: A framework. Journal of Marketing Communications. Journal of Marketing Communications, 23(2), 149-161.

Park, C., Wang, Y., Yao, Y., \& Kang, Y. R. (2011). Factors Influencing eWOM Effects: Using Experience, Credibility, and Susceptibility. International Journal of Social Science and Humanity, 1(1), 74-79.

Prihatini, R. (2017). Merek lokal masih mendominasi pasar kosmetik. Retrieved from http://industri.kontan.co.id/news/merek-lokalmasih-mendominasi-pasar-kosmetik

Schiffman, L., \& Kanuk, L. (2010). Consumer Behavior (10th ed.). New Jersey: Pearson.

Srivastava, K., \& Sharma, N. (2016). Consumer perception of brand personality: An empirical evidence from India. Global Business Review. Global Business Review, 17(2), 375-388.

Tai, J., \& Chew, W. (2012). Killer Differentiators: 13 Strategies to Grow Your Brand [Brand Management: 13 Strategi untuk Mengembangkan Merek Anda]. Jakarta: Indeks.

Themba, G., \& Mulala, M. (2013). Brand-Related eWOM and Its Effects on Purchase Decisions: An Empirical Study of University of Botswana Students. International Journal of Business and Management, 8(8), 31-40.

Vazifehdoost, H., \& Hamedani, S. E. A. (2016). The Role of Brand Personality in Consumer's Decision Making: A Review of The Literature. International Journal of Research in IT, Management and Engineering, 6(4), 15-29.

Zhang, X. A. (2017). Effects of Twitter communication styles on consumers' brand personality perceptions, attitudes and purchase intentions. International Journal of Internet Marketing and Advertising, 11(2), 158-182. 